Int. J. Dev. Biol. 62: 145-152 (2018)

https://doi.org/10.1387/ijdb.170283jh

\title{
The early development of germ cells in chicken
}

\author{
YOUNG MIN KIM and JAE YONG HAN* \\ Department of Agricultural Biotechnology and Research Institute of Agriculture and Life Sciences, \\ College of Agriculture and Life Sciences, Seoul National University, Seoul, Korea
}

\begin{abstract}
Primordial germ cells (PGCs) are the founder cells for mature gametes, the vehicles by which individuals transmit genetic and epigenetic information to later generations. Since the $19^{\text {th }}$ century, avian species (chickens in particular) have been widely used for germ cell research. Previous studies have used chicken PGCs for a variety of research applications, including as a model for studies focusing on germline development. Other applications of chicken PGCs, including conservation efforts for avian species and methods of producing transgenic birds, have further reinforced the importance of these cells. However, much remains to be revealed about the origin and role of PGCs during their development in the chicken. Here, we provide a comprehensive review of chicken PGCs, focusing in particular upon their initial profiles and physiological changes during development as regulated by environmental factors and/or intrinsic mechanisms. We also emphasise sex-dependent differences in PGC development after settlement within the gonads, as well as future applications for avian PGCs.
\end{abstract}

KEY WORDS: primordial germ cell, origin, migration, specification, chicken

\section{Introduction}

Germ cells are the only cells that can transfer the entirety of an organism's genetic information to the next generation. In many multicellular organisms, mature gametes, including sperm or eggs, originate from primordial germ cells (PGCs). PGCs occupy a small proportion of the early embryo and are clearly distinguishable from somatic cells. In the fields of developmental and evolutionary biology, gaining a comprehensive understanding of the underlying mechanisms for germ cell specification is a major goal. Germ cells are important not only for basic biological research, but also as a means of preserving genetic resources. Thus, how and when germ cells are initially originated and specified is a crucial question. There are two general models of germ cell specification: preformation and induction (Extavour and Akam, 2003). The preformation model involves germ cell determinants, which are unique cytoplasmic organelles generically termed 'germ granules' or 'germ plasm.' These organelles contain maternally inherited mRNAs, proteins, and small RNAs, and play a crucial role in germ cell specification in Caenorhabditis elegans, Drosophila melanogaster, Danio rerio, and Xenopus laevis (Strome and Wood, 1983; Hay et al., 1988; Ephrussi et al., 1991; Tada et al., 2012; Strome and Updike, 2015). On the other hand, in the induction model (which applies to taxa including Homo sapiens and Mus musculus) germ cells arise from proximal-posterior epiblasts, a process induced by bone morphoge- netic protein (BMP) signalling from neighbouring extra-embryonic tissue during gastrulation (Lawson et al., 1999; Tang et al., 2016a).

In avian species, PGCs are initially detected as a scattered pattern in the area pellucida, the central region of Eyal-Giladi and Korchav (EGK) stage X embryos (Eyal-Giladi and Kochav, 1976; Ginsburg and Eyal-Giladi, 1987; Tsunekawa et al., 2000). Between EGK stage $X$ and Hamburger and Hamilton $(\mathrm{HH})$ stage 2 (Hamburger and Hamilton, 1951), PGCs are moved passively by the overall movement of embryonic cells; they actively move to the germinal crescent at $\mathrm{HH}$ stage 4 (Swift, 1914; Hamburger and Hamilton, 1951; Eyal-Giladi et al., 1981). Subsequently, between $\mathrm{HH}$ stages 9 and 12, PGCs move into blood vessels and circulate through the bloodstream (Fujimoto et al., 1976; Ukeshima et al., 1991), finally settling in the genital ridge (Meyer, 1964; Fujimoto et al., 1976). To date, although numerous studies have been performed to elucidate the origin and specification of avian PGCs, they still remain incompletely defined. Here, we review when, where, and how these cells originate and are specified. Furthermore, we explore the current state of knowledge regarding molecular events in the development of avian PGCs and discuss their use in certain practical applications.

Abbreviations used in this paper: EGK, Eyal-Giladi and Korchav (stage); HH, Hamburger and Hamilton stage; PGC, primordial germ cell.

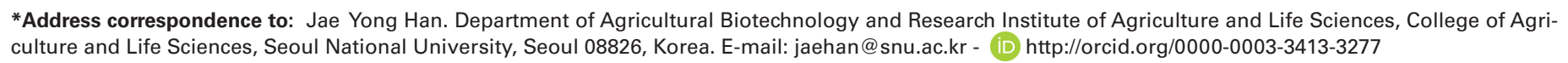




\section{Early studies in chicken PGCs}

Since the first observations of the origin of germ cells in chicken germinal epithelium by Waldeyer in 1870, chickens have been regarded as an ideal model species for germ cell research (Waldeyer, 1870). In 1880, Nussbaum claimed that PGCs are derived from a much earlier stage in embryonic formation (Nussbaum, 1880), and Swift suggested that PGCs arise from the margin of the area pellucida in the early stages of chick development, and referred to the marginal crescentshaped region as the 'germinal crescent' (Swift, 1914). Swift also discovered that PGCs migrate via the bloodstream to all parts of the embryo and area vasculosa when blood vessels form in the mesoderm layer (Swift, 1914). Owing to the lack of reliable markers for PGCs, the process of specification for avian PGCs remained unclear for several decades. However, early researchers agreed on many points that PGCs arise from the anterior region of the embryo at the margin of the area pellucida from the primitive streak stage to the three-somite stage, then migrate to newly formed blood vessels by amoeboid movement, enter the bloodstream, and travel to the germinal epithelium (Swift, 1914; Firket, 1920; Goldsmith, 1928).

Early studies on avian PGCs focused on characterising their morphological appearance. Swift described PGCs as interspersed with hypoblast cells, and noted that they could be distinguished from neighbouring cells based on their size and the presence of many glycogen granules in the cytoplasm (Swift, 1914). Meyer found that histochemically staining of these large glycogen granules with periodic acid-Schiff (PAS) made it possible to identify PGCs at early embryonic stages (Meyer, 1960; Meyer, 1964). In late 1960s, it was proposed that PGCs originated prior to the formation of the primitive streak, at $\mathrm{HH}$ stage 3 and earlier (Clawson and Domm, 1969). By staining PGCs with PAS reagent at $\mathrm{HH}$ stages 4 to 7, Clawson and Domm found that 100-250 PGCs were already present at these stages (Clawson and Domm, 1969; Fujimoto et al., 1976). In subsequent studies, Sutasurya et al., found that chicken PGCs exist before the primitive streak formation by at least HH stage 4 (Sutasurya et al., 1983) and Ginsburg and Eyal-Giladi suggested that chicken PGCs already be determined earlier than EGK stage $X$ and that their further differentiation is independent of the embryo-forming process based on PAS staining results (Ginsburg and Eyal-Giladi, 1987).

\section{Origin and specification of chicken PGCs}

In 1976, Eyal-Giladi and Kochav proposed that clustered PGCs were found in chicken blastoderm at EGK stage $X$ to $\mathrm{HH}$ stage 2 (Eyal-Giladi and Kochav, 1976). Subsequent chick-quail chimera studies showed that PGCs originate in the epiblast layer (Eyal-Giladi et al., 1981), and that only the central region of the blastoderm can give rise to PGCs (Ginsburg and Eyal-Giladi, 1987; Ginsburg et al., 1989). In order to investigate more reliable data for the origin of PGCs in situ, Urven et al., applied the Equi merozoite antigen 1 (EMA-1), a monoclonal antibody produced against cell surface of the murine embryonic carcinoma cells, to chicken PGCs (Urven et al., 1988). Like PAS, EMA-1 identified the chicken PGCs from the germinal crescent to the migratory stage and also in sexually differentiated gonad (Urven et al., 1988). Another mouse embryonal carcinoma surface marker, stage-specific embryonic antigen 1 (SSEA-1), also successfully detected the PGCs at EGK stage X (Karagenc et al., 1996). In more recent studies, researchers showed that chicken PGCs were efficiently isolated using SSEA-1 antibody and the isolation method allowed to examine the molecular profiles of chicken PGCs in more detail (Mozdziak et al., 2006; Motono et al., 2008). In particular, the studies using the antibody showed that SSEA-1-positive cells express the genes related to germ cell inductive signals, such as Blimp1 (also known as Prdm1) and Itgb1 (also known as CD29), which are known to be the core genes for PGC development and specification in other species (Ancelin et al., 2006; Kunwar et al., 2006). The results suggest that avian PGCs arise at around EGK stage $X$ in response to inductive signals might be a well-founded conjecture.

Nevertheless, the hypothesis that the germ cells are specified by maternally inherited factors, preformation mode, has been widely accepted. In 2000, chicken vasa homologue (CVH), a reliable germ cell marker, was used to identify chicken PGCs in developmental stages. Immunohistochemical analyses showed that $\mathrm{CVH}$-expressing cells were detectable during early embryogenesis, starting from the first cleavage of fertilised eggs to functional oocyte (Tsunekawa et al., 2000). The VASA protein is an ATP-dependent RNA helicase in the DEAD-box family, and the proteins are highly conserved among distantly related species including $C$. elegans, $D$. melanogaster, $D$. rerio, $X$. laevis, and $M$. musculus. It has known as one of the components of the germ plasm, and plays an essential role in germ cell development in diverse animal species (Hay et al., 1990; Lasko and Ashburner, 1990; Gruidl et al., 1996; Ikenishi and Tanaka, 1997). In the Drosophila polar granules, the VASA protein is observed to co-localise with spectrin and mitochondrial clouds, and the protein is also detected with the putative germ plasm of oocytes and cleavage-stage embryos in Xenopus (Hay et al., 1988; Kloc and Etkin, 1998). Similar to Drosophila and Xenopus, VASA protein of chicken is localised in oocytes in granulofibrillar structures surrounding the mitochondrial cloud and spectrin protein-enriched structure, indicating that the $\mathrm{CVH}$-containing structure is the germ plasm in the chicken. Furthermore, $\mathrm{CVH}$ was found in cleavage furrows and was restricted to only 6-8 cells in 300-cell-stage embryos (Tsunekawa et al., 2000). Based on these findings, germ cell specification in the chicken may follow the preformation model and be specified by maternal determinants. More recently, Lee et al., identified the expression of deleted in azoospermia-like ( $D A Z L)$, another functional protein expressed in germline cells in embryos, during the intrauterine stages before oviposition (Lee et al., 2016a). DAZL, which is another germline-specific RNA-binding protein, is well studied in vertebrate species for its role in meiotic progression and maintaining germ cell pluripotency (Eberhart et al., 1996; Haston et al., 2009). Using chicken $D A Z L$ as a germ plasm marker, Lee et al., observed that the germ granule exhibited asymmetric localisation in oocytes, and shifted from a subcellular localisation to a diffuse form during cleavage at the point of zygotic genome activation. Furthermore, aberrant $D A Z L$ expression affects $P G C$ proliferation, gene expression, and apoptosis in vitro, suggesting that it plays a role in germ cell integrity in chickens (Lee et al., 2016a). These results further reinforce the notion that PGCs originate through maternally inherited components, and that PGCs form before the epiblast although further researches are required to 
examine the specific functions of germ plasm components and clarify the mechanisms of germ cell specification in avian species.

\section{Epigenetic regulation of chicken PGCs}

Epigenetic dynamics are crucial for early embryonic development and PGCs. During embryogenesis in mouse and humans, PGCs undergo unique epigenetic reprogramming processes including genome-wide demethylation, X chromosome inactivation, histone modification, and transposon silencing regardless of somatic cells (Saitou et al., 2012). In C. elegans, epigenetic regulations including histone modifications activating germline genes and repressing somatic genes also play a critical role in germ cell developmental programming (Strome and Updike, 2015).

In avian species, the nature of epigenetic reprogramming during germ cell development has not yet been established. However, recent studies showed that the epigenetic signature in chicken PGCs includes DNA methylation, histone modification, and post-transcriptional regulation by small RNAs (Jang et al., 2013; Rengaraj et al., 2014; Kress et al., 2016).Through methylation, mammalian PGCs establish monoallelic expression of imprinting genes, maintain inactivated retrotransposons, inactivate one of the two $\mathrm{X}$ chromosomes, and suppress gene expression (Lees-Murdock and Walsh, 2008). In chicken, PGCs contain differentially methylated regions detected in male and female, which also found in the imprinting and X-linked homologous regions in mammals, suggesting that epigenetic mechanisms are evolutionarily conserved between mammals and birds (Jang et al., 2013).

In addition to DNA methylation, post-translational histone modifications also specify the cellular fate of PGCs (Tang et al., 2016a). Moreover, chicken PGCs exhibit trimethylation of histone $\mathrm{H} 3$ on lysine 9 (H3K9me3) during heterochromatin formation. Conversely, mice exhibit trimethylation of histone $\mathrm{H} 3$ on lysine 27 (H3K27me3) by polycomb proteins. This demonstrates that the avian-specific chromatin constitution differs from the mammalian epigenetic system (Kress et al., 2016).

With respect to post-transcriptional regulation, small RNAs, including microRNAs (miRNAs) and piwi-interacting RNAs (piRNAs), are also required for PGC and germline development in mouse, zebrafish, and fly (Hayashi et al., 2008; Thomson and Lin, 2009). In the chicken, small RNAs are known to have important functions in maintaining germ cell integrity. Lee et al., identified chicken PGC-specific miRNAs using microarray analysis. Especially, miR-181-3p was found to have multiple functions in chicken PGCs, including inhibiting somatic differentiation and preventing meiotic progression of PGCs by suppressing homeobox $A 1$ and nuclear receptor subfamily 6, group A, member 1 (NR6A1) expression (Lee et al., 2011). Recently, several germ cell-specific piRNAs, which can be classified as repetitive-element-sequence-derived or protein-coding-gene-derived based on their genomic origins, have been identified in the chicken PGCs. As in other species, piRNAs and piRNA pathway genes are required for the genome integrity of chicken PGCs (Rengaraj et al., 2014). In summary, research on epigenetics in avian germ cells remains in its infancy. Future studies will elucidate the epigenetic functions in avian PGCs using the latest next-generation sequencing technology.

\section{Migration of chicken PGCs}

Cell migration plays important roles in a wide variety of biological phenomena. In developmental biology, identifying the mechanisms of cell migration is essential for understanding the formation of different tissues (Ribeiro et al., 2003; Blackburn and Manley, 2004; Mammoto and Ingber, 2010; Herriges and Morrisey, 2014). During gastrulation, an embryo undergoes coordinated cell movement and is reorganised to form the three germ layers (Keller, 2005). In most vertebrates, germ cells are specified in one region of the embryo, then migrate extensively before reaching the genital ridge in the initial phase of development (Richardson and Lehmann, 2010). The phenomenal pathway of germ cells has been studied in various species including the fly, fish, mouse, and chicken (Sasado et al., 2004; Richardson and Lehmann, 2010; Nakamura et al., 2013; Kang et al., 2015; Paksa and Raz, 2015). As one of example, in mice, PGCs are first identifiable as a cluster of cells in the proximal epiblast region. They then migrate to the extra-embryonic ectoderm (ExE) (Lawson and Hage, 1994; Hayashi et al., 2007), and subsequently through the developing endodermal hindgut into the genital ridges (Richardson and Lehmann, 2010).

In chicken, PGCs undergo multiple stages of motility and proliferation. They are initially localised in the central zone of the area pellucida, settling on the expanding hypoblast from the epiblast at EGK stage $X$, and are then gradually translocated from this region (Ginsburg and Eyal-Giladi, 1986). PGCs first undergo passive movement, regulated by primitive streak formation, from the central zone of the area pellucida to the anterior region; next, they adhere to fibrous bands on basement membranes of the epiblast of the area pellucida (Wakely and England, 1979). Through a transplantation study using DF1 and PGC cell lines, Kang et al., demonstrated that PGCs that passively reach the anterior region, are actively incorporated into the germinal crescent (Kang et al., 2015). However, the process of active migration to the germinal crescent, guided by attractive and repulsive cues, remains poorly understood. Several research groups have shown that some migratory and cultured PGCs produce pseudopodia, suggesting amoeboid movement as a possible means of migration (Fujimoto et al., 1976; Kuwana et al., 1987; Choi et al., 2010). PGCs penetrate into blood vessels by $\mathrm{HH}$ stages 9-10, and are most abundant at $\mathrm{HH}$ stage 12 (Fujimoto et al., 1976; Lee et al., 1978). Circulating PGCs in the blood stream reach the genital ridge and invade the thickened coelomic epithelium from $\mathrm{HH}$ stage 15 to $\mathrm{HH}$ stage 18 (Ukeshima et al., 1987; Nakamura et al., 2007). In 1986, Kuwana et al., suggested that the coelomic epithelium may release a chemical cue that attracts PGCs to the gonads (Kuwana et al., 1986). They isolated PGCs from $\mathrm{HH}$ stage 13 embryos, then placed the PGCs between the germinal ridge and other embryonic tissues (such as the neural tube, heart, allantois, and liver) in vitro and the PGCs moved only towards the germinal ridge, suggesting that they are attracted by specific signals that it emits (Kuwana et al., 1986). Two decades later, Stebler et al., revealed that the main molecules that guide the migration of chicken PGCs are chemokine stromal cell-derived factor 1 (SDF-1/CXCL12) and its receptor, G-protein-coupled receptor 4 (CXCR4), which is expressed by migrating PGCs (Stebler et al., 2004). A more 
recent study found that anterior vitelline veins play a key role in directly accumulating migrating PGCs, which reach the genital ridges during circulation (De Melo Bernardo et al., 2012). Collectively, Figure 1 represents the migration and development of chicken PGCs in early embryogenesis (Fig. 1).

\section{Development of chicken germ cells in the sex cord}

After migration into embryonic gonads and following sex differentiation, PGCs undergo mitotic/meiotic switch in female and undergo mitotic arrest after gonadal sex differentiation in male (Etches, 1995; Howarth, 1995). The decision of germ cells whether to enter meiosis or mitosis depends on signals from the environment surrounding the germ cells, especially retinoic acid (RA) signaling (Bowles et al., 2006; Griswold et al., 2012). In the mouse, RA is produced in the mesonephric kidney and diffuses into the fetal gonad. In the gonad, RA acts on germ cells and promotes the expression of a gene called stimulated by retinoic acid 8 (Stra8). Stra8 stimulates meiotic entry for germ cells by regulating the expression of meiotic markers (Bowles et al., 2006). In male mouse embryos, the expression of a gene called cytochrome P450 family 26 subfamily b member 1 (Cyp26b1), which encodes an enzyme that degrades RA, is upregulated in gonads and prevents Stra8 expression in male germ cells (Bowles et al., 2006). It is also known that fibroblast growth factor 9 (FGF9), which is secreted by foetal testis cells, acts on germ cells and promotes the expression of male germ cell specific genes such as Nanos2 (Bowles et al., 2010). These male germ cell specific genes inhibit meiotic entry and maintain mitotic arrest in spermatogonia

In the chicken, at E.8 female PGCs in the germinal epithelium are more numerous than in earlier stages (Swift, 1915). This stage is the beginning of the rapid mitotic cell division of PGCs at the time of gonadal sex differentiation in the ovarian cortex (Mendez et al., 2005). It has been shown that STRA8 is the driving factor for the initiation of meiosis in chicken germ cells, as it is in mammalian species (Smith et al., 2008). Before the initiation of meiosis, retinaldehyde dehydrogenase $2(R A L D H 2)$ and STRA8expression begins at E.12.5 and meiotic germ cells can be observed at E15.5 (Smith et al., 2008). The expression of RALDH2 and STRA8 is restricted to the left gonadal cortex, the site where meiosis occurs (Smith et al., 2008). When RALDH2or STRA8expression is inhibited by short hairpin RNA (shRNA), the number of meiotic germ cells decreases. In contrast, RA treatment increases STRA8 expression and the number of meiotic germ cells in the embryonic ovary (Yu et al., 2013). These results show that RA signalling is a conserved mechanism for initiating meiotic entry across vertebrates. Recently, it was also shown that polycomb repressive complex 1 (PRC1) controls the timing of meiotic entry by epigenetically regulating the expression of STRA8, as well as Notch ligands such as jadomycin polyketide synthase cyclase (JAD1) and delta-like 1 (DLL1), in female chick embryos (Tang et al., 2016b). Basic fibroblast growth factor (bFGF) signalling, which is important for PGC proliferation and survival, can suppress meiotic initiation of germ cells independently from RA signalling; furthermore, the expression of bFGF in the ovarian cortex decreases markedly throughout meiosis (Choi et al., 2010; He et al., 2012). After meiotic initiation, female germ

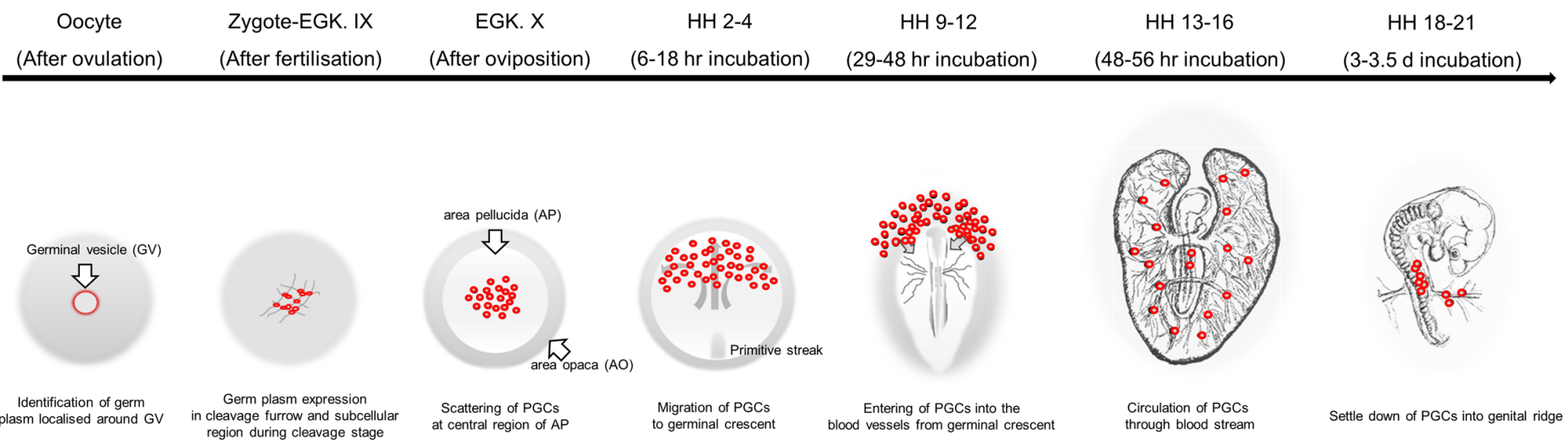

VASA

DAZL

\begin{tabular}{l} 
SSEA-1 \\
EMA-1 \\
\hline PAS \\
\hline \\
\hline
\end{tabular}

Fig. 1. Schematic representation of primordial germ cell (PGC) development and markers expression. The germ plasms, sUCh as VASA and DAZL, are maternally inherited and expressed in the germinal vesicle (GV) of chicken oocyte and cleavage furrow and subcellular region following cleavage stages indicating predetermined precursor PGC. At stage X (after oviposition), PGCs that express VASA and DAZL are scattered at the central zone of the area pellucida. PGCS are positive for SSEA-1 and EMA-1 antibodies, and PAS staining at Stage X. Subsequently, they move to the anterior marginal zone, following epiblast and hypoblast layer movement, and finally they are localized into the germinal crescent. And PGCs of the germinal crescent enter into extraembryonic blood vessels then circulate through the bloodstream. Finally, PGCs attracted by SDF1 interact with the chemokine receptor CXCR4 and invade the coelomic epithelium of the genital. This figure is modified from Nieuwkoop and Sutasurya (1979) and Lee et al., (2016a). 
cells undergo meiotic arrest at the diplotene stage before and after hatching (Zheng et al., 2009).

In male chick embryos, PGCs do not proliferate significantly after gonadal sex differentiation and undergo mitotic arrest at E8.0 and remain as pro-spermatogonia at the G1 stage of the cell cycle until hatching (Kirby and Froman, 2000). CYP26B1 is expressed in the male gonads of chick embryos throughout development, as it is in mammalian species (Smith et al., 2008). However, in female embryos, the level of CYP26B1 decreases from E12.5 and STRA8 expression increases (Smith et al., 2008). These results indicate that CYP26B1 degrades RA in male gonads to prevent meiotic entry of germ cell in chick embryos. Other signalling pathways that act on spermatogonia to prevent meiotic initiation and induce male germ cell-specific genes have not yet been clearly defined in the chicken.

\section{Application of avian PGCs}

Since the migratory route for avian PGCs differ from mammalian species (Niewkoop and Sutasurya, 1979), they can be isolated at various stages of embryonic development. This characteristic provides them with a huge advantage in germ cell research. Various methods have been used to isolate PGCs from embryonic tissue or blood vessels, including fluorescence-activated cell sorting (FACS), magnetic-activated cell sorting (MACS) using PGC-specific antibodies, and density gradient centrifugation, and size-dependent isolation without using antibodies (Chang et al., 1992; Ono and Machida, 1999; Zhao and Kuwana, 2003; Mozdziak et al., 2005; Jung et al., 2017).

PGC isolation have been attempted not only in chicken, but also in other avian species such as pheasant, quail, turkey, duck and guinea fowl, and have been produced using PGCs for the purpose of restoring endangered birds (Reynaud, 1969; Ono et al., 1996; Kang et al., 2008; Wernery et al., 2010; Liu et al., 2012; van de Lavoir et al., 2012). However, historically the germline transmission rate of donor-derived progeny has been prohibitively low, owing to differences between species in traits such as reproductive cycle. $\mathrm{PGC}$ culture is therefore required for endangered bird restoration efforts, but the culture process has not yet been fully optimised.

Among aves, the long-term culture system of chicken PGC has been successfully established (van de Lavoir et al., 2006). It has been shown that bFGF plays an essential role in the proliferation and survival of chicken PGCs via the mitogen-activated protein kinase kinase (MEK) / extracellular signal-regulated kinases (ERK) signaling pathway, and helps to maintain telomerase activity, migratory activity, and germline contribution in PGCs cultured for extended periods (Choi et al., 2010; Macdonald et al., 2010). More recent studies have shown that MEK1, AKT (also known as protein kinase $B, P K B$ ), and SMAD family member 3 (SMAD-3) signalling is required for $P G C s$ to maintain germline transmission capacity, and that Wnt/ $\beta$-catenin signalling is required for PGC proliferation in vitro (Whyte et al., 2015; Lee et al., 2016b). Furthermore, it has been reported that stem cell factor 2 (SCF2) derived from chickens has potent and prolonged effects on PGC proliferation via FGF2- and c-KIT-mediated growth signals, and is thus crucial for the maintenance of germ cell characteristics and germ line transmission (Daichi et al., 2016).

Cultured PGCs have been utilised not only for research on germ cell signalling pathways (Choi et al., 2010; Whyte et al., 2015; Lee et al., 2016b), but also for transgenic studies (van de Lavoir et al., 2006). Transgenic poultry has the potential to be used for the production of pharmaceutical and industrial proteins in eggs (Ivarie, 2003; Sang, 2004; Han, 2009) and several successfully generated transgenic chickens as a bioreactor have been reported indeed (Zhu et al., 2005; Lillico et al., 2007; Cao et al., 2015). Recently, genome-editing tools such as transcription activator-like effector nuclease (TALEN) and clustered regularly interspaced short palindromic repeat (CRISPR)/CRISPR-associated protein (CRISPR/ Cas) have been adapted as promising methods for developing avian model (Park et al., 2014; Dimitrov et al., 2016; Oishi et al., 2016; Taylor et al., 2017). Applying such germline modification techniques combined with PGC culture to a variety of valuable avian species will permit expansion of this research area and have considerable benefits for the poultry industry.

\section{Conclusion}

For over 100 years, many researchers have sought to understand the origin and development of germ cells, the only cells that contain the entirety of an individual's genomic information. With struggling of researchers in avian biology, we could know basic knowledge on avian germ cells including its origin, specification, migration and differentiation. However, large portion of avian germ cell biology including germ cell origin, specification and the regulatory mechanisms for germ cell development (including epigenetic factors) are still unknown. New, cutting-edge technologies for isolation, germ cell culture system, and genome-editing will likely permit further insight into the origin and developmental fate of germ cells.

\section{Acknowledgements}

This work was supported by a National Research Foundation of Korea (NRF) grant funded by the Korea government (MSIP) (No. 2015R1A3A2033826).

\section{References}

ANCELIN, K., LANGE, U.C., HAJKOVA, P., SCHNEIDER, R., BANNISTER, A.J., KOUZARIDES, T. and SURANI, M.A. (2006). Blimp1 associates with Prmt5 and directs histone arginine methylation in mouse germ cells. Nat Cell Bio/8: 623-630.

BLACKBURN, C.C. and MANLEY, N.R. (2004). Developing a new paradigm for thymus organogenesis. Nat Rev Immunol 4: 278-289.

BOWLES, J., FENG, C.W., SPILLER, C., DAVIDSON, T.L., JACKSON, A. and KOOPMAN, P. (2010). FGF9 suppresses meiosis and promotes male germ cell fate in mice. Dev Cell 19: 440-449.

BOWLES, J., KNIGHT, D., SMITH, C., WILHELM, D., RICHMAN, J., MAMIYA, S., YASHIRO, K., CHAWENGSAKSOPHAK, K., WILSON, M.J., ROSSANT, J. et al., (2006). Retinoid signaling determines germ cell fate in mice. Science 312: 596-600.

CAO, D., WU, H., LI, Q., SUN, Y., LIU, T., FEI, J., ZHAO, Y., WU, S., HU, X. and LI, N. (2015). Expression of recombinant human lysozyme in egg whites of transgenic hens. PLoS One 10: e0118626.

CHANG, I., TAJIMA, A., YASUDA, Y., CHIKAMUNE, T. and OHNO, T. (1992). Simple method for isolation of primordial germ cells from chick embryos. Cell Biol Int Rep 16: 853-857.

CHOI, J.W., KIM, S., KIM, T.M., KIM, Y.M., SEO, H.W., PARK, T.S., JEONG, J.W., SONG, G. and HAN, J.Y. (2010). Basic fibroblast growth factor activates MEK/ ERK cell signaling pathway and stimulates the proliferation of chicken primordial germ cells. PLoS One 5: e12968.

CLAWSON, R.C. and DOMM, L.V. (1969). Origin and early migration of primordial germ cells in the chick embryo: a study of the stages definitive primitive streak through eight somites. Am J Anat 125: 87-111.

DAICHI, M., ISAO, O., RYUICHI, M., NOZOMI, K., RYUMA, N., TAMAO, O., HIRO- 
SHI, K. and TAKAHIRO, T. (2016). Chicken stem cell factor enhances primordial germ cell proliferation cooperatively with fibroblast growth factor 2. J Reprod Dev 62: 143-149.

DE MELO BERNARDO, A., SPRENKELS, K., RODRIGUES, G., NOCE, T. and CHUVA DE SOUSA LOPES, S.M. (2012). Chicken primordial germ cells use the anterior vitelline veins to enter the embryonic circulation. Biol Open 1: 1146-1152.

DIMITROV, L., PEDERSEN, D., CHING, K.H., YI, H., COLLARINI, E.J., IZQUIERDO, S., VAN DE LAVOIR, M.C. and LEIGHTON, P.A. (2016). Germline Gene Editing in Chickens by Efficient CRISPR-Mediated Homologous Recombination in Primordial Germ Cells. PLoS One 11: e0154303.

EBERHART, C.G., MAINES, J.Z. and WASSERMAN, S.A. (1996). Meiotic cell cycle requirement for a fly homologue of human Deleted in Azoospermia. Nature 381 783-785.

EPHRUSSI, A., DICKINSON, L.K. and LEHMANN, R. (1991). Oskar organizes the germ plasm and directs localization of the posterior determinant nanos. Cell 66: 37-50.

ETCHES, R.J. (1995). Physiology of reproduction: the female. In: Hunton P (ed) Poultry production. Elsevier, Amsterdam. 221-241.

EXTAVOUR, C.G. and AKAM, M. (2003). Mechanisms of germ cell specification across the metazoans: epigenesis and preformation. Development 130: 5869-5884.

EYAL-GILADI, H., GINSBURG, M. and FARBAROV, A. (1981). Avian primordial germ cells are of epiblastic origin. J Embryol Exp Morphol 65: 139-147.

EYAL-GILADI, H. and KOCHAV, S. (1976). From cleavage to primitive streak formation: a complementary normal table and a new look at the first stages of the development of the chick. I. General morphology. Dev Biol 49: 321-337.

FIRKET, J. (1920). On the origin of germ cells in higher vertebrates. Anat. Rec. 18: 309-316.

FUJIMOTO, T., UKESHIMA, A. and KIYOFUJI, R. (1976). The origin, migration and morphology of the primordial germ cells in the chick embryo. AnatRec 185: 139-145.

GINSBURG, M. and EYAL-GILADI, H. (1986). Temporal and spatial aspects of the gradual migration of primordial germ cells from the epiblast into the germinal crescent in the avian embryo. J Embryol Exp Morphol 95: 53-71.

GINSBURG, M. and EYAL-GILADI, H. (1987). Primordial germ cells of the young chick blastoderm originate from the central zone of the area pellucida irrespective of the embryo-forming process. Development 101: 209-219.

GINSBURG, M., HOCHMAN, J. and EYAL-GILADI, H. (1989). Immunohistochemical analysis of the segregation process of the quail germ cell lineage. Int $J \mathrm{Dev}$ Biol 33: 389-395

GOLDSMITH, J.B. (1928). The history of the germ cells in the domestic fowl. J. Morphol. 46: 275-315.

GRISWOLD, M.D., HOGARTH, C.A., BOWLES, J. and KOOPMAN, P. (2012). Initiating meiosis: the case for retinoic acid. Biol Reprod 86: 35

GRUIDL, M.E., SMITH, P.A., KUZNICKI, K.A., MCCRONE, J.S., KIRCHNER, J., ROUSSELL, D.L., STROME, S. and BENNETT, K.L. (1996). Multiple potential germ-line helicases are components of the germ-line-specific $\mathrm{P}$ granules of $\mathrm{Cae}$ norhabditis elegans. Proc Natl Acad Sci USA 93: 13837-13842.

HAMBURGER, V. and HAMILTON, H.L. (1951). A series of normal stages in the development of the chick embryo. J Morphol 88: 49-92.

HAN, J.Y. (2009). Germ cells and transgenesis in chickens. Comp Immunol Microbiol Infect Dis 32: 61-80.

HASTON, K.M., TUNG, J.Y. and REIJO PERA, R.A. (2009). Dazl functions in maintenance of pluripotency and genetic and epigenetic programs of differentiation in mouse primordial germ cells in vivo and in vitro. PLoS One 4: e5654.

HAY, B., JAN, L.Y. and JAN, Y.N. (1988). A protein component of Drosophila polar granules is encoded by vasa and has extensive sequence similarity to ATPdependent helicases. Cell 55: 577-587.

HAY, B., JAN, L.Y. and JAN, Y.N. (1990). Localization of vasa, a component of Drosophila polar granules, in maternal-effect mutants that alter embryonic anteroposterior polarity. Development 109: 425-433.

HAYASHI, K., CHUVADE SOUSA LOPES, S.M., KANEDA, M., TANG, F., HAJKOVA, P., LAO, K., O'CARROLL, D., DAS, P.P., TARAKHOVSKY, A., MISKA, E.A. et al., (2008). MicroRNA biogenesis is required for mouse primordial germ cell development and spermatogenesis. PLoS One 3: e1738.

HAYASHI, K., DE SOUSA LOPES, S.M. and SURANI, M.A. (2007). Germ cell specification in mice. Science 316: 394-396.

HE, B., LIN, J., LI, J., MI, Y., ZENG, W. and ZHANG, C. (2012). Basic fibroblast growth factor suppresses meiosis and promotes mitosis of ovarian germ cells in embryonic chickens. Gen Comp Endocrinol 176: 173-181.

HERRIGES, M. and MORRISEY, E.E. (2014). Lung development: orchestrating the generation and regeneration of a complex organ. Development 141: 502-513.

HOWARTH, B. (1995). Physiology of reproduction: the male. In: Hunton P (ed) Poultry production. Elsevier, Amsterdam. 243-270

IKENISHI, K. and TANAKA, T.S. (1997). Involvement of the protein of Xenopus vasa homolog (Xenopus vasa-like gene 1, XVLG1) in the differentiation of primordia germ cells. Dev Growth Differ 39: 625-633.

IVARIE, R. (2003). Avian transgenesis: progress towards the promise. Trends Biotechnol 21: 14-19.

JANG, H.J., SEO, H.W., LEE, B.R., YOO, M., WOMACK, J.E. and HAN, J.Y. (2013). Gene expression and DNA methylation status of chicken primordial germ cells. Mol Biotechnol 54: 177-186.

JUNG, K., KIM, Y., ONO, T. and HAN, J. (2017). Size-dependent isolation of primordial germ cells from avian species. Mol Reprod Dev 84: 508-516.

KANG, K.S., LEE, H.C., KIM, H.J., LEE, H.G., KIM, Y.M., LEE, H.J., PARK, Y.H., YANG, S.Y., RENGARAJ, D., PARK, T.S. et al., (2015). Spatial and temporal action of chicken primordial germ cells during initial migration. Reproduction 149: 179-187.

KANG, S.J., CHOI, J.W., KIM, S.Y., PARK, K.J., KIM, T.M., LEE, Y.M., KIM, H., LIM, J.M. and HAN, J.Y. (2008). Reproduction of wild birds via interspecies germ cell transplantation. Biol Reprod 79: 931-937.

KARAGENC, L., CINNAMON, Y., GINSBURG, M. and PETITTE, J.N. (1996). Origin of primordial germ cells in the prestreak chick embryo. Dev Genet 19: 290-301.

KELLER, R. (2005). Cell migration during gastrulation. Curr Opin Cell Biol17:533-541.

KIRBY, J.D. and FROMAN, D.P. (2000). Reproduction in male birds. In Avian Physiology. Ed. GC Whittow. San Diego: Academic Press. 5th edition: 597-615.

KLOC, M. and ETKIN, L.D. (1998). Apparent continuity between the messenger transport organizer and late RNA localization pathways during oogenesis in Xenopus. Mech Dev 73: 95-106.

KRESS, C., MONTILLET, G., JEAN, C., FUET, A. and PAIN, B. (2016). Chicken embryonic stem cells and primordial germ cells display different heterochromatic histone marks than their mammalian counterparts. Epigen. Chromatin 9: 5.

KUNWAR, P.S., SIEKHAUS, D.E. and LEHMANN, R. (2006). In vivo migration: a germ cell perspective. Annu Rev Cell Dev Biol 22: 237-265.

KUWANA, T., MAEDA-SUGA, H. and FUJIMOTO, T. (1986). Attraction of chick primordial germ cells by gonadal anlage in vitro. Anat Rec 215: 403-406.

KUWANA, T., MIYAYAMA, Y., KAJIWARA, Y. and FUJIMOTO, T. (1987). Behavior of chick primordial germ cells moving toward gonadal primordium in vitro: scanning electron microscopic study. Anat Rec 219: 164-170.

LASKO, P.F. and ASHBURNER, M. (1990). Posterior localization of vasa protein correlates with, but is not sufficient for, pole cell development. Genes Dev 4: 905-921.

LAWSON, K.A., DUNN, N.R., ROELEN, B.A., ZEINSTRA, L.M., DAVIS, A.M., WRIGHT, C.V., KORVING, J.P. and HOGAN, B.L. (1999). Bmp4 is required for the generation of primordial germ cells in the mouse embryo. Genes Dev 13: 424-436.

LAWSON, K.A. and HAGE, W.J. (1994). Clonal analysis of the origin of primordial germ cells in the mouse. Ciba Found Symp 182: 68-84; discussion 84-91.

LEE, H., KARASANYI, N. and NAGELE, R.G., JR. (1978). The role of the cell surface in the migration of primordial germ cells in early chick embryos: effects of concanavalin A. J Embryol Exp Morphol 46: 5-20.

LEE, H.C., CHOI, H.J., LEE, H.G., LIM, J.M., ONO, T. and HAN, J.Y. (2016a). DAZL Expression Explains Origin and Central Formation of Primordial Germ Cells in Chickens. Stem Cells Dev 25: 68-79.

LEE, H.C., LIM, S. and HAN, J.Y. (2016b). Wnt/beta-catenin signaling pathway activation is required for proliferation of chicken primordial germ cells in vitro. Sci Rep 6: 34510.

LEES-MURDOCK, D.J. and WALSH, C.P. (2008). DNA methylation reprogramming in the germ line. Epigenetics 3: 5-13.

LILLICO, S., SHERMAN, A., MCGREW, M., ROBERTSON, C., SMITH, J., HASLAM, C., BARNARD, P., RADCLIFFE, P., MITROPHANOUS, K., ELLIOT, E. etal., (2007). Oviduct-specific expression of two therapeutic proteins in transgenic hens. Proc Natl Acad Sci USA 104: 1771-1776.

LIU, C., KHAZANEHDARI, K.A., BASKAR, V., SALEEM, S., KINNE, J., WERNERY, U. and CHANG, I.K. (2012). Production of chicken progeny (Gallus gallus domesticus) 
from interspecies germline chimeric duck (Anas domesticus) by primordial germ cell transfer. Biol Reprod 86: 101.

MACDONALD, J., GLOVER, J.D., TAYLOR, L., SANG, H.M. and MCGREW, M.J. (2010). Characterisation and germline transmission of cultured avian primordial germ cells. PLoS One 5: e15518.

MAMMOTO, T. and INGBER, D.E. (2010). Mechanical control of tissue and organ development. Development 137: 1407-1420.

MENDEZ, C., CARRASCO, E. and PEDERNERA, E. (2005). Adenohypophysis regulates cell proliferation in the gonads of the developing chick embryo. J Exp Zool A Comp Exp Biol 303: 179-185.

MEYER, D.B. (1960). Application of the periodic acid-schiff technique to wholee chick embryos. Stain Tech. 35: 83-89.

MEYER, D.B. (1964). The Migration of Primordial Germ Cells in the Chick Embryo. Dev Biol 10: 154-190.

MOTONO, M., OHASHI, T., NISHIJIMA, K. and IIJIMA, S. (2008). Analysis of chicken primordial germ cells. Cytotechnology 57: 199-205.

MOZDZIAK, P.E., ANGERMAN-STEWART, J., RUSHTON, B., PARDUE, S.L. and PETITTE, J.N. (2005). Isolation of chicken primordial germ cells using fluorescenceactivated cell sorting. Poult Sci. 84: 594-600.

MOZDZIAK, P.E., WYSOCKI, R., ANGERMAN-STEWART, J., PARDUE, S.L. and PETITTE, J.N. (2006). Production of chick germline chimeras from fluorescenceactivated cell-sorted gonocytes. Poult Sci 85: 1764-1768.

NAKAMURA, Y., KAGAMI, H. and TAGAMI, T. (2013). Development, differentiation and manipulation of chicken germ cells. Dev Growth Differ 55: 20-40.

NAKAMURA, Y., YAMAMOTO, Y., USUI, F., MUSHIKA, T., ONO, T., SETIOKO, A.R., TAKEDA, K., NIRASAWA, K., KAGAMI, H. and TAGAMI, T. (2007). Migration and proliferation of primordial germ cells in the early chicken embryo. Poult Sci 86: 2182-2193.

NIEWKOOP, P. and SUTASURYA, L. (1979). Primordial Germ Cells in the Chordates. Cambridge Univ, Press, Cambridge.

NUSSBAUM, M. (1880). Zur Differenzierung des Geschlechts im Tierreich. Arch Mikrosk Ant 18.

OISHI, I., YOSHII, K., MIYAHARA, D., KAGAMI, H. and TAGAMI, T. (2016). Targeted mutagenesis in chicken using CRISPR/Cas9 system. Sci Rep 6: 23980.

ONO, T. and MACHIDA, Y. (1999). Immunomagnetic purification of viable primordial germ cells of Japanese quail (Coturnix japonica). Comp Biochem Physiol A Mol Integr Physiol 122: 255-259.

ONO, T., YOKOI, R. and AOYAMA, H. (1996). Transfer of Male or Female Primordial germ cells of quail into chick embryonic gonads. Exp Anim 45: 347-352.

PAKSA, A. and RAZ, E. (2015). Zebrafish germ cells: motility and guided migration. Curr Opin Cell Biol 36: 80-85.

PARK, T.S., LEE, H.J., KIM, K.H., KIM, J.S. and HAN, J.Y. (2014). Targeted gene knockout in chickens mediated by TALENs. Proc Natl Acad Sci USA 111: 12716-12721.

RENGARAJ, D., LEE, S.I., PARK, T.S., LEE, H.J., KIM, Y.M., SOHN, Y.A., JUNG, M., NOH, S.J., JUNG, H. and HAN, J.Y. (2014). Small non-coding RNA profiling and the role of piRNA pathway genes in the protection of chicken primordial germ cells. BMC Genomics 15: 757.

REYNAUD, G. (1969). The transfer of turkey primordial germ cells to chick embryos by intravascular injection. J Embryol Exp Morphol 21: 485-507.

RIBEIRO, C., PETIT, V. and AFFOLTER, M. (2003). Signaling systems, guided cell migration, and organogenesis: insights from genetic studies in Drosophila. Dev Biol 260: 1-8.

RICHARDSON, B.E. and LEHMANN, R. (2010). Mechanisms guiding primordial germ cell migration: strategies from different organisms. Nat Rev Mol Cell Biol11:37-49.

SAITOU, M., KAGIWADA, S. and KURIMOTO, K. (2012). Epigenetic reprogramming in mouse pre-implantation development and primordial germ cells. Development 139: 15-31.

SANG, H.M. (2004). Transgenics, chickens and therapeutic proteins. Vox Sang 87 Suppl 2: 164-166

SASADO, T., MORINAGA, C., NIWA, K., SHINOMIYA, A., YASUOKA, A., SUWA, H., HIROSE, Y., YODA, H., HENRICH, T., DEGUCHI, T. et al., (2004). Mutations affecting early distribution of primordial germ cells in Medaka (Oryzias latipes) embryo. Mech Dev 121: 817-828.

SMITH, C.A., ROESZLER, K.N., BOWLES, J., KOOPMAN, P. and SINCLAIR, A.H.
(2008). Onset of meiosis in the chicken embryo; evidence of a role for retinoic acid. BMC Dev Biol 8: 85

STEBLER, J., SPIELER, D., SLANCHEV, K., MOLYNEAUX, K.A., RICHTER, U., COJOCARU, V., TARABYKIN, V., WYLIE, C., KESSEL, M. and RAZ, E. (2004). Primordial germ cell migration in the chick and mouse embryo: the role of the chemokine SDF-1/CXCL12. Dev Biol 272: 351-361.

STROME, S. and UPDIKE, D. (2015). Specifying and protecting germ cell fate. Nat Rev Mol Cell Biol 16: 406-416.

STROME, S. and WOOD, W.B. (1983). Generation of asymmetry and segregation of germ-line granules in early $C$. elegans embryos. Cell 35: 15-25.

SUTASURYA, L.A., YASUGI, S. and MIZUNO, T. (1983). Appearance of Primordial Germ Cells in Young Chick Blastoderms Cultured in vitro. Dev. Growth Differ. 25: 517-521.

SWIFT, C.H. (1914). Origin and early history of the primordial germ cells of the chick. Am. J. Anat. 18: 483-516.

SWIFT, C.H. (1915). Origin of the definitive sex-cells in the female chick and their relation to the primordial germ-cells. Am. J. Anat. 18: 441-470.

TADA, H., MOCHII, M., ORII, H. and WATANABE, K. (2012). Ectopic formation of primordial germ cells by transplantation of the germ plasm: direct evidence for germ cell determinant in Xenopus. Dev Biol 371: 86-93.

TANG, W.W., KOBAYASHI, T., IRIE, N., DIETMANN, S. and SURANI, M.A. (2016a). Specification and epigenetic programming of the human germ line. Nat Rev Genet 17: 585-600.

TANG, X., XU, S., LI, R., ZHANG, H., CHEN, Q., WU, W. and LIU, H. (2016b). Polycomb repressive complex 1 (PRC1) regulates meiotic initiation of ovarian germ cells in chick embryos. Mol Cell Endocrinol 437: 171-182.

TAYLOR, L., CARLSON, D.F., NANDI, S., SHERMAN, A., FAHRENKRUG, S.C. and MCGREW, M.J. (2017). Efficient TALEN-mediated gene targeting of chicken primordial germ cells. Development 144: 928-934.

THOMSON, T. and LIN, H. (2009). The biogenesis and function of PIWI proteins and piRNAs: progress and prospect. Annu Rev Cell Dev Biol 25: 355-376.

TSUNEKAWA, N., NAITO, M., SAKAI, Y., NISHIDA, T. and NOCE, T. (2000). Isolation of chicken vasa homolog gene and tracing the origin of primordial germ cells. Development 127: 2741-2750.

UKESHIMA, A., KUDO, M. and FUJIMOTO, T. (1987). Relationship between genital ridge formation and settlement site of primordial germ cells in chick embryos. Anat Rec 219: 311-314.

UKESHIMA, A., YOSHINAGA, K. and FUJIMOTO, T. (1991). Scanning and transmission electron microscopic observations of chick primordial germ cells with special reference to the extravasation in their migration course. J Electron Microsc (Tokyo) 40: 124-128.

URVEN, L.E., ERICKSON, C.A., ABBOTT, U.K. and MCCARREY, J.R. (1988). Analysis of germ line development in the chick embryo using an anti-mouse EC cell antibody. Development 103: 299-304.

VAN DE LAVOIR, M.C., COLLARINI, E.J., LEIGHTON, P.A., FESLER, J., LU, D.R., HARRIMAN, W.D., THIYAGASUNDARAM, T.S. and ETCHES, R.J. (2012). Interspecific germline transmission of cultured primordial germ cells. PLoS One 7: e35664.

VAN DE LAVOIR, M.C., DIAMOND, J.H., LEIGHTON, P.A., MATHER-LOVE, C. HEYER, B.S., BRADSHAW, R., KERCHNER, A., HOOI, L.T., GESSARO, T.M., SWANBERG, S.E. et al., (2006). Germline transmission of genetically modified primordial germ cells. Nature 441: 766-769.

WAKELY, J. and ENGLAND, M.A. (1979). Scanning electron microscopical and histochemical study of the structure and function of basement membranes in the early chick embryo. Proc R Soc Lond B Biol Sci 206: 329-352.

WALDEYER, W. (1870). Eirstock und Ei. Eine Beitrag zur Anatomie und Entwicklungsgeschichte der Sexualorgane. Leipzig.

WERNERY, U., LIU, C., BASKAR, V., GUERINECHE, Z., KHAZANEHDARI, K.A., SALEEM, S., KINNE, J., WERNERY, R., GRIFFIN, D.K. and CHANG, I.K. (2010). Primordial germ cell-mediated chimera technology produces viable pure-line Houbara bustard offspring: potential for repopulating an endangered species. PLoS One 5: e15824.

WHYTE, J., GLOVER, J.D., WOODCOCK, M., BRZESZCZYNSKA, J., TAYLOR, L., SHERMAN, A., KAISER, P. and MCGREW, M.J. (2015). FGF, Insulin, and SMAD Signaling Cooperate for Avian Primordial Germ Cell Self-Renewal. Stem Cell Reports 5: 1171-1182. 
YU, M., YU, P., LEGHARI, I.H., GE, C., MI, Y. and ZHANG, C. (2013). RALDH2, the enzyme for retinoic acid synthesis, mediates meiosis initiation in germ cells of the female embryonic chickens. Amino Acids 44: 405-412.

ZHAO, D.F. and KUWANA, T. (2003). Purification of avian circulating primordial germ cells by Nycodenz density gradient centrifugation. Brit. Poultry Sci. 44: 30-35.

ZHENG, Y.H., RENGARAJ, D., CHOI, J.W., PARK, K.J., LEE, S.I. and HAN, J.Y.
(2009). Expression pattern of meiosis associated SYCP family members during germline development in chickens. Reproduction 138: 483-492.

ZHU, L., VAN DE LAVOIR, M., ALBANESE, J., BEENHOUWER, D., CARDARELLI, P., CUISON, S., DENG, D., DESHPANDE, S., DIAMOND, J., GREEN, L. et al., (2005). Production of human monoclonal antibody in eggs of chimeric chickens. Nat Biotechnol 23: 1159-1169.

\section{Further Related Reading, published previously in the Int. J. Dev. Biol.}

Chicken primordial germ cell motility in response to stem cell factor sensing

Thanida Srihawong, Takashi Kuwana, Kannika Siripattarapravat and Chanin Tirawattanawanich

Int. J. Dev. Biol. (2015) 59: 453-460

https://doi.org/10.1387/ijdb.140287ct

The problem of the origin of primordial germ cells (PGCs) in vertebrates: historical review and a possible solution Giovanni Pilato, Vera D’Urso, Fabio Viglianisi, Francesca Sammartano, Giorgio Sabella and Oscar Lisi Int. J. Dev. Biol. (2013) 57: 809-819

https://doi.org/10.1387/ijdb.120261gp

Molecular aspects of avian oogenesis and fertilisation

Bozenna Olszanska and Urszula Stepinska

Int. J. Dev. Biol. (2008) 52: 187-194

https://doi.org/10.1387/ijdb.072329ob

Germinal tumor invasion and the role of the testicular stroma

Alejandro Díez-Torre, Unai Silván, Olivier De Wever, Erik Bruyneel, Marc Mareel and Juan Aréchaga

Int. J. Dev. Biol. (2004) 48: 545-557

http://www.intjdevbiol.com/web/paper/041897ad

Crescent, a novel chick gene encoding a Frizzled-like cysteine-rich domain, is expressed in anterior regions during early embryogenesis

P L Pfeffer, E M De Robertis and J C Izpisua-Belmonte

Int. J. Dev. Biol. (1997) 41: 449-458

http://www.intjdevbiol.com/web/paper/9240561

Immunohistochemical analysis of the segregation process of the quail germ cell lineage M Ginsburg, J Hochman and H Eyal-Giladi

Int. J. Dev. Biol. (1989) 33: 389-395

http://www.intjdevbiol.com/web/paper/2702123

5 yr ISI Impact Factor $(2016)=2.421$
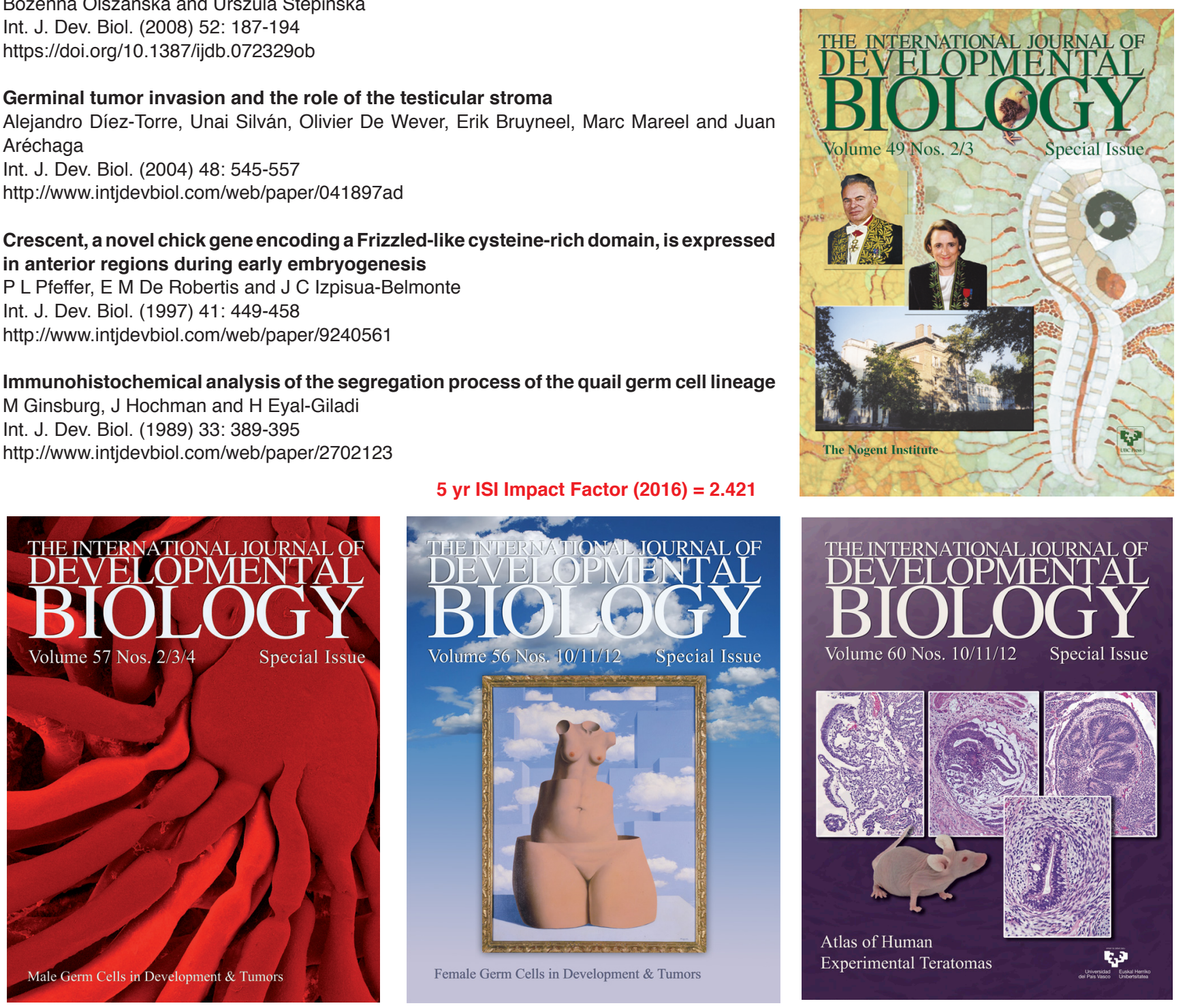